\title{
Outcomes following calcium channel blocker exposures reported to a poison information center
}

Mikkel B. Christensen ${ }^{1,2^{*}}$, Kasper M. Petersen ${ }^{1}$, Søren Bøgevig ${ }^{1}$, Salam Al-Gibouri ${ }^{1}$, Espen Jimenez-Solem ${ }^{1,2}$, Kim P. Dalhoff ${ }^{1,2}$, Tonny S. Petersen ${ }^{1,2}$ and Jon T. Andersen ${ }^{1,2}$

\begin{abstract}
Background: Calcium channel blockers (CCBs) are widely used drugs that have a narrow therapeutic index. Even minor overdoses must be treated in-hospital due to the risk of severe hypotension and bradycardia. We aimed to describe trends in CCB use and overdoses in Denmark.

Methods: Data on enquiries concerning CCBs reported to the Danish Poisons Information Center (DPIC) from January 2009 to January 2015 was coupled with data on hospitalization and mortality obtained from Danish National Registers. We obtained data on the general use of CCBs in Denmark and retrieved medical charts on fatal cases.

Results: From a total of 126,987 enquiries to the DPIC in 2009-2014 we identified 339 CCB unique exposures (3\%o of all). Children < 5 years accounted for 20\% all exposures and these were classified as 'intake during playing' (61\%) and 'medication errors' (39\%). Among adults 'suicidal poisonings' (58\%), and 'medication errors' (34\%) were most frequent. A majority (81\%) of exposures led to hospital admission. Seven patients (2\%) died from the CCB exposure and all were adults with 'suicidal poisoning'. Amlodipine accounted for $95 \%$ of all CCB prescriptions, was involved in $71 \%$ of enquiries and in $29 \%$ of fatalities. Verapamil accounted for $3 \%$ of prescriptions, was involved in $13 \%$ of enquiries and $57 \%$ of fatalities.
\end{abstract}

Conclusion: Four fifths of enquiries to the DPIC result in hospitalization and one fifth concern small children. Mortality were infrequent and occurred only in adults with suicidal exposures and with and an overrepresentation of verapamil exposures.

Keywords: Overdose, Poisoning, Calcium channel blockers, Calcium antagonist, Verapamil, Amlodipin, Felodipin, Isradipin, Lacidipin, Lercanidipin, Nifedipin, Nimodipin, Nitrendipin, Diltiazem

\footnotetext{
* Correspondence: mikkel.bring.christensen@regionh.dk

${ }^{1}$ Department of Clinical Pharmacology, Copenhagen University Hospital

Bispebjerg, Bispebjerg Bakke 23, DK-2400 Copenhagen, Denmark

${ }^{2}$ Faculty of Health and Medical Sciences, University of Copenhagen,

Copenhagen, Denmark
}

(c) The Author(s). 2018 Open Access This article is distributed under the terms of the Creative Commons Attribution 4.0 International License (http://creativecommons.org/licenses/by/4.0/), which permits unrestricted use, distribution, and reproduction in any medium, provided you give appropriate credit to the original author(s) and the source, provide a link to the Creative Commons license, and indicate if changes were made. The Creative Commons Public Domain Dedication waiver (http://creativecommons.org/publicdomain/zero/1.0/) applies to the data made available in this article, unless otherwise stated. 


\section{Background}

Calcium channel blockers (CCBs) are widely used drugs indicated for the treatment of cardiovascular disease and migraine. CCBs have a narrow therapeutic index, and consequently even minor overdoses have to be treated in-hospital due to the risk of severe hypotension and bradycardia [1, 2]. All of the CCBs block L-type voltage gated calcium channels, but individual agents differ in chemical structure and tissue selectivity [3]. At therapeutic doses CCBs belonging to the dihydropyridine class (e.g. amlodipine and felodipine) are primarily affecting calcium channels in the smooth muscle in peripheral vessels, whereas non-dihydropyridine agents (verapamil and diltiazem) are also affecting calcium channels in the heart [2, 3]. Tissue selectively has been reported to be attenuated with increasing doses, but nonetheless, non-dihydropyridine overdoses often leads to various degrees of conduction block and are therefore considered most dangerous [1, 2]. Metabolic and central nervous system (CNS) disturbances are also seen after CCB overdoses, but the cause of death after CCB toxicity is usually presumed to be circulatory collapse [1-4]. Thus, advising about and caring for patients, who have ingested CCBs deliberately or unintentionally is a challenging health care task; and there is limited information on the pharmacoepidemiology and outcomes of overdoses with CCBs. The objectives of this study are to describe trends in the general use of CCBs and to describe causes and consequences of $\mathrm{CCB}$ poisonings based on data from the Danish Poisons Information Center (DPIC), Danish national registers and medical charts.

\section{Methods}

\section{Data}

In this retrospective study we identified all patients poisoned with $\mathrm{CCBs}$ from the DPIC-database from January 1st, 2009 to December 31st 2014. The DPIC is a telephone-based, 24-h service providing information on a national level to guide the public and health care professionals on all aspects related to acute poisonings including the management of the poisoned patient. All telephone enquiries to the DPIC are registered in a database with information on the suspected poisoning. The following are recorded: patient data including the unique personal identification number, a description of the poisoning (poison, amount in DDD, mode of exposure, etc.), clinical status of the patient, and the cause of poisoning. The cause of poisoning was divided into 'suicidal intake' or 'accidental intake', 'abuse' or 'other'. Accidental intake includes 'intake during playing' and 'medication errors' e.g. incorrect dosage or drug, accident, or confusion of pills.

In the DPIC-database we identified all inquiries concerning CCBs by searching for synonyms of CCBs combined with all generic and brand names of $\mathrm{CCBs}$ marketed in Denmark during the study period. Only records with a complete personal identification number and a registration of a possible CCB overdose or poisoning were included in the study. The DPIC records of $\mathrm{CCB}$ exposures were then linked with hospital records from the Danish National Hospital Register [5] and information on death was retrieved from the Danish Register of Causes of Death [6]. All records were linked using the unique Danish personal identification number [7], which all persons living in Denmark get at birth or following immigration to Denmark.

The National Hospital Registry contains information on all hospitalizations and outpatient visits in Denmark, including 99\% of all discharge records, length of hospital stay and discharge diagnoses (International Classification of Diseases 10th Edition (ICD-10) Danish revision) [5]. The Danish Register of Causes of Death holds information on all deaths in Denmark including place, time, and cause of death classified using ICD-10 Danish revision codes [6].

Sales numbers for CCBs expressed in Defined Daily Doses (DDDs) in the primary and secondary sectors in Denmark were extracted as additional information from the online database MEDSTAT [8].

Detailed medical charts for the fatal cases (identified through national registers) were retrieved from the hospital departments, where these patients were admitted.

\section{Statistics}

All analyses and data management were performed using SAS statistical software version 9.4 (SAS Institute Inc., Cary, NC, USA). Frequency distributions comparisons were analysed with Fisher's exact test. For all analyses, a two-sided value of $p<0.05$ was considered statistically significant, and all odds ratios are presented with 95\% confidence intervals. Graphical presentation was prepared using Graphpad Prism version 7.02 (La Jolla, CA, USA).

\section{Results}

From a total of 126,987 enquiries to the DPIC in 2009-2014 we identified 339 records (3\% of all) concerning patients with a CCB exposure, where outcome data was available through the national registries (Fig. 1). 


\section{Description of population Age and gender distribution}

The age distribution among patients with a CCB exposure was bimodal with a peak in the preschool children and in adults aged $40-80$ years (Fig. 2).

Children (i.e. boys and girls $<16$ years) accounted for $24 \%$ of all CCB enquires $(N=78)$, and the youngest age group 0-5 years accounted for $20 \%$ all exposures $(N=69)$. There were slightly more boys $(56 \%)$ among exposed children, whereas females were the majority in individuals above 16 years of age (61\%) $(p<0.01)$.

\section{Reason for exposure}

Suicidal exposures accounted for $46 \%$ of all enquiries. However, the reason for exposure differed across age groups. Only 6\% $(N=5)$ of the children's cases were caused by suicidal exposures, all concerning girls aged $13-15$ years. The major reason for exposure $(85 \%)$ in children were 'medication errors' $(40 \%)$ or 'intake during playing' (54\%). In the youngest age (i.e. < 5 years) group reasons for exposure were 'intake during playing' (61\%) and 'medication errors' (39\%). The age group 16-65 years had a high proportion $(71 \%)$ of suicidal exposures compared to the age group above 65 years $(35 \%)(p<0.0001)$. The accidental exposures in the above 65 years age-group were most often (55\%) 'medication errors'.

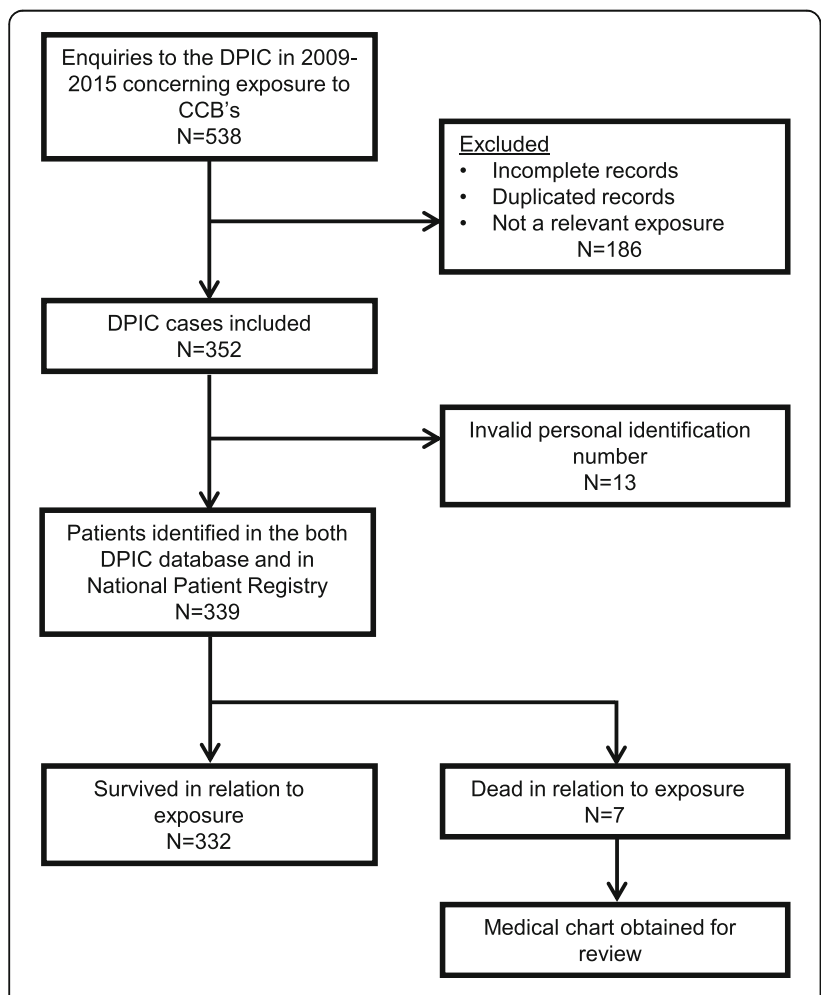

Fig. 1 Flow Chart for patient inclusion

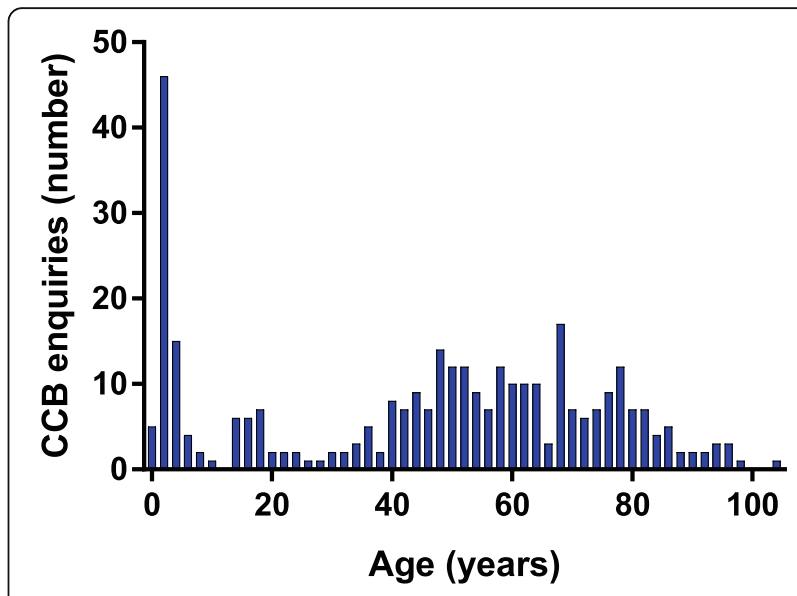

Fig. 2 Age distribution among CCB exposures registered by the Danish Poison Information Center from 2009 to 2014

CCBs involved in poisonings and their sales in Denmark Single drug exposures constituted $35 \%$ of all cases, but $65 \%$ of exposures in children. The majority (78\%) of accidental exposures concerned intake of only one $\mathrm{CCB}$, whereas the majority (84\%) of suicidal exposures the CCBs were taken with other substances (i.e. mixed exposures). Among all enquiries (i.e. both suicidal and accidental) concerning CCBs, amlodipine was the most common and was involved in $72 \%(N=249)$ of the cases, whereas verapamil was involved in $13 \%(N=45)$, felodipine in $5 \%(N=16)$, and diltiazem in $5 \%(N=16)$.

From 2009 to 2015, the sale of dihydropyridine CCBs increased, whereas sales of verapamil and diltiazem slightly decreased (Fig. 3a). The population-corrected frequency of enquiries concerning CCBs were 61 enquiries per million citizens (Fig. 3, Table 1 in appendix), with an increasing trend in enquiries over the study period (Fig. 3b).

\section{Outcome of exposure \\ Hospital admission}

A majority (81\%) of cases were admitted to a hospital. Children were admitted in $88 \%$ of exposures, and adults were admitted in $78 \%$ of exposures. In adults with clear anamnestic information on exposure dose the length of in-hospital stay increased with higher DDD-intake/exposure of both dihydropyridine and non-dihydropyridine CCBs (Fig. 4). In children, the anamnestic information on dosage was too uncertain (e.g. worst-case scenarios) for the purpose of relating DDDs to length of hospital stay. In children the length of in-hospital stay had a median value of 1 day (range 0-4 days): Dihydropyridines accounted for 25 exposures in children that subdivided into: 4 exposures leading to: 0 days in-hospital stay; 17 exposures: 1 day; 3 exposures: 2 days; 1 exposure: 4 days. Verapamil intake by children accounted for six exposures: 2 


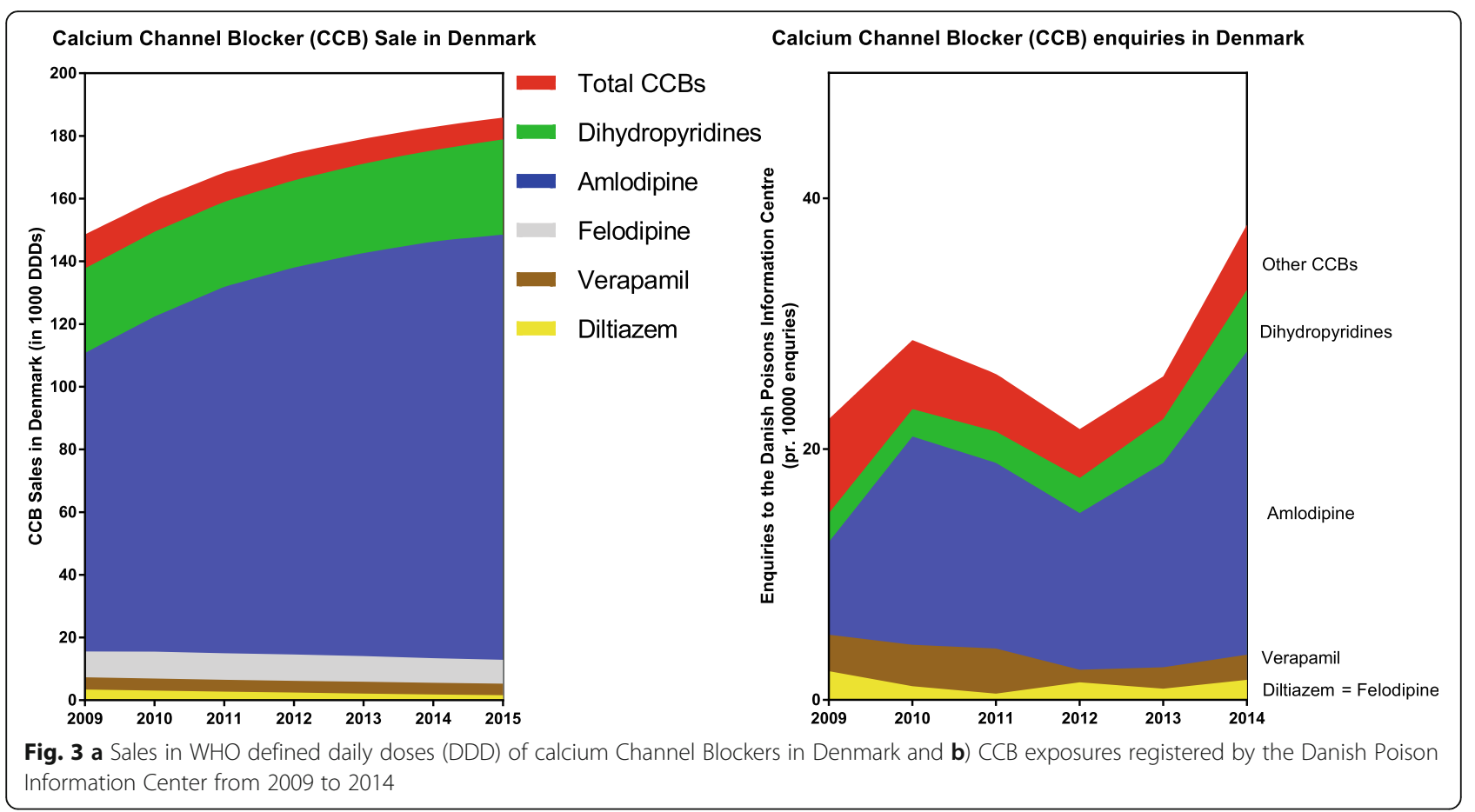

exposures led to 1 day in-hospital stay and 4 exposures led to 3 days in-hospital stay.

\section{Mortality following CCB exposure}

Seven patients (2\%) died within 30 days after CCB exposure, but one of the patients did not die from $\mathrm{CCB}$ poisoning (Table 2 in Appendix presents details from these lethal cases). Mortality occurred only in adults with suicidal exposures, and the lethal cases were all mixed exposures. The CCB's involved were verapamil $(N=4)$, amlodipine $(N=2)$ or felodipine $(N=1)$. Of the four adults who died after verapamil exposure, information on intake was available for two, who ingested 25 and 100 DDDs, respectively. There were no deaths among 120 enquiries concerning an isolated intake of dihydropyridine CCB (both adults and children) - even after a severe overdose (e.g. in 6 patients with exposures exceeding 100 DDDs).

\section{Discussion}

We report that despite enquiries to the DPIC concerning CCBs being relatively infrequent, four-fifth of exposures resulted in hospitalization and $2 \%$ led to death. In that context, we find it reassuring that mortality only occurred in adults with suicidal intent. One fourth of exposures concerned children, and there were no deaths or prolonged in-hospital stays in pre-school children.

Our data may therefore be used to question the relatively cautious guidelines for out-of-hospital management of CCB overdoses recommending that intake of amlodipine and
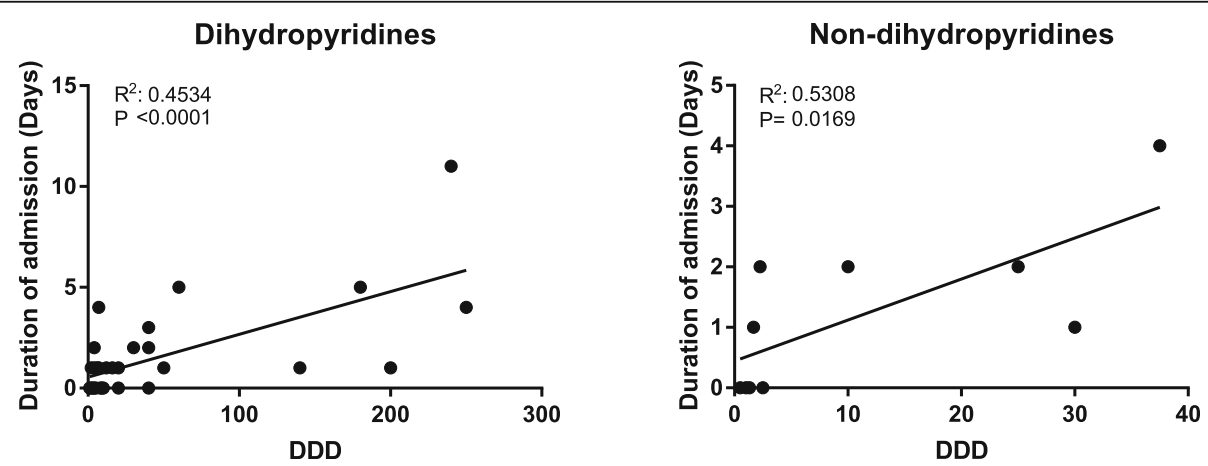

Fig. 4 Association of dose of CCB exposure (expressed in DDD) with duration of in-hospital stay in adults for a) the dihydropyridines (mostly amlodipine) or b) non-dihydropyridines (verapamil) 
felodipine doses of $0.3 \mathrm{mg} / \mathrm{kg}$ and $10 \mathrm{mg}$ (2 DDDs) in children and adults, respectively, should be referred to the emergency department [1]. Our data is quite accurate on length of hospital stay and there were only very few in-hospital stays $>1$ day in children after accidental dihydropyridine or verapamil overdoses. A similar finding was also reported by others, where intake of a relatively large amount of CCBs did not give rise to major symptoms in children under the age of 6 years $[9,10]$. However, our data material is not precise enough on symptomatology or large enough to contradict reports of significant hypotension or severe toxicity even after minor accidental exposures $([1,11]$.

The finding of no fatalities in adults following accidental exposures (i.e. not counting suicidal or abuse exposures), are in line with other reports. Generally deaths have only rarely been reported following unintentional intake of CCBs and often other important complicating factors may have played important roles for the fatal course e.g. serious co-exposures such as other cardioactive drugs, co-morbidity such as heart failure, or very low age $[1,12]$. It is noteworthy that there were no deaths in adults following isolated intake of dihydropyridines, which are by far the most widely used CCBs, even after intake of up to 200 DDDs. In contrast, verapamil was involved in four out of seven deaths despite only being involved in $13 \%$ of enquiries and in $3-5 \%$ of the total CCB sale in Denmark. Thus, our results seem to corroborate the larger risk attributed to verapamil also reported by others $[1,4,13]$. Our thorough review of the fatal cases underlines the differences between verapamil and dihydropyridines in toxicity: All verapamil overdoses presented with severe cardiotoxicity and conduction abnormalities (i.e. 3rd degree atrioventricularand/or left bundle branch blocks, pulseless electric activity) that deteriorated after arrival and led to death within 3 days (Table 2 in Appendix). Of the two fatal dihydropyridine cases (one amlodipine and one felodipine), the felodipine exposure did not present with or develop in-hospital severe cardiac disturbances but died after 8 days of hypoxic-ischemic brain damage (developed before arrival to the hospital and likely related to co-ingestion of codeine and quinine). The fatal amlodipine exposure died of severe cardiotoxicity but had also co-ingested metoprolol and enalapril - whereof both, but in particular metoprolol is known to exert synergistic cardiodepressive effects with CCBs.

A particular problem evident from the fatal cases presented in Table 2 in Appendix is the apparent lack of alignment with current treatment recommendations [14], which in all cases was advocated by the DPIC. Particular, therapies such as high-dose insulin (used in two of six cases), high-dose glucagon (used in three of six cases), and high-dose intravenous lipid emulsion (used in one of six cases), seem underused. Findings of lack of adherence to guidelines and poison center advice have also been reported by others $[15,16]$.

Collectively, our findings correlate reasonably with other publications describing CCB exposures [1, 9, 17-20]. However, there are some discrepancies worth noticing. Our rate of hospital admission (81\%) appears high compared to previous reports of approximately 50-73\% hospital admissions following CCB exposures $[1,17]$ and may reflect the severity of exposures reported to the DPIC, where approximately half of the exposures were suicidal. Olson et al. [1] described death to occur only after verapamil, nifedipine, and diltiazem and Deters et al. [18] described death to occur most frequently after diltiazem exposures. In our material, nifedipine and diltiazem was only involved in few exposures and not involved in fatal cases. This difference likely reflects the relatively infrequent use of nifedipine and diltiazem in Denmark, where sales are decreasing for older dihydropyridines (e.g. nifedipine) and non-dihydropyridines (verapamil and diltiazem).

\section{Strengths and limitations}

This study covers nationwide follow-up data in our study population due to the completeness of the Danish National Health Registers. Thus, we have reliable outcome data on all patients studied. Nevertheless, the major limitations of this study relate to the completeness of data: We identified exposures through the enquiries to the DPIC, and therefore these cases may not be representative all the CCB exposures in Denmark; some exposures may be handled at home or be hospitalized or die without contact to the DPIC. Furthermore, as discussed previously we have limited data on clinical symptoms and our data reflects the clinical scenario in acute poisonings, thus anamnestic information concerning exposures, i.e. dose and potential co-ingestants are somewhat uncertain - and in this retrospective study no formal validation (i.e. measurement of plasma concentration etc.) of offending drugs could be performed.

\section{Conclusion}

From 2009 to 2014, the sale of dihydropyridine CCBs increased in Denmark, whereas sales of verapamil and diltiazem slightly decreased. In the same period, enquiries to the DPIC concerning CCBs were rare (3\% of all enquiries), but often serious and with $80 \%$ resulting in hospitalization. One fourth of exposures concerned children and most of these were monoexposures. There were no deaths among 120 enquiries concerning an isolated intake of dihydropyridine CCB (both adults and children) even after a severe overdose (e.g. in 6 patients with exposures exceeding 100 DDDs). Amlodipine accounted for $95 \%$ of all CCB prescriptions, was involved in $71 \%$ of enquiries and in $29 \%$ of fatalities. Verapamil accounted for $3 \%$ of prescriptions, was involved in $13 \%$ of enquiries and $57 \%$ of fatalities. Mortality occurred in $2 \%(N=7)$ and only in adults with suicidal exposures. 


\section{Appendix}

Table 1 Citizens, CCB-related enquiries, and CCB sales and in Denmark 2009-2014

\begin{tabular}{|c|c|c|c|c|c|c|}
\hline Year & 2009 & 2010 & 2011 & 2012 & 2013 & 2014 \\
\hline Danish population in persons & $5,532,531$ & $5,557,709$ & $5,579,204$ & $5,599,665$ & $5,623,501$ & $5,655,750$ \\
\hline CCB related enquiries & 40 & 52 & 57 & 44 & 61 & 89 \\
\hline Total CCB sale in DDD & 148,626 & 159,483 & 168,374 & 174,585 & 179,149 & 182,916 \\
\hline Dihydropyridines sale in DDD (\% of total CCB sale) & $137,779(93)$ & $149,428(94)$ & $159,057(94)$ & $165,904(95)$ & $171,181(96)$ & $175,518(96$ \\
\hline Amlodipine sale in DDD (\% of total CCB sale) & $110,792(75)$ & $122,425(77)$ & $131,922(78)$ & $138,074(79)$ & $142,678(80)$ & $146,330(80$ \\
\hline Verapamil sale in DDD (\% of total CCB sale) & $7314(4.9)$ & $6940(4.4)$ & $6543(3.9)$ & $6201(3.6)$ & $5872(3.3)$ & $5566(3.0)$ \\
\hline Diltiazem sale in DDD (\% of total CCB sale) & $3409(2.3)$ & 3079 (1.9) & $2764(1.6)$ & $2480(1.4)$ & $2096(1.2)$ & $1832(1.0)$ \\
\hline
\end{tabular}

Table 2 Fatal cases

\begin{tabular}{|c|c|c|c|c|c|c|}
\hline $\begin{array}{l}\text { Gender } \\
\text { and age }\end{array}$ & Comorbidity & $\begin{array}{l}\text { Anamnestic } \\
\text { drug exposure } \\
\text { (doses noted if } \\
\text { known) }\end{array}$ & $\begin{array}{l}\text { Interval to } \\
\text { presentation } \\
\text { and death } \\
\text { post intake }\end{array}$ & $\begin{array}{l}\text { Clinical presentation at } \\
\text { hospital } \\
\text { Time from intake to } \\
\text { admission if known) and } \\
\text { symptoms (GCS, } \\
\text { temperature, } \\
\text { hemodynamic, renal, } \\
\text { other }\end{array}$ & $\begin{array}{l}\text { Paraclinical parameters } \\
\text { Arterial blood gas (pH, } \\
\text { base excess, lactate) } \\
\text { blood samples (e.g. } \\
\text { glucose, calcium,) and } \\
\text { ECGs }\end{array}$ & $\begin{array}{l}\text { Treatment } \\
\text { Gastrointestinal decontamination (e.g. } \\
\text { gastric emptying, activated charcoal). } \\
\text { Inotropes, vasopressors and } \\
\text { vasoactive therapy (e.g. isoprenaline, } \\
\text { norepinephrine). } \\
\text { Other interventions (e.g. dialysis, } \\
\text { calcium, glucagon) }\end{array}$ \\
\hline $\begin{array}{l}\text { Female, } \\
82 \text { y }\end{array}$ & $\begin{array}{l}\text { Morbus } \\
\text { Meniere. } \\
\text { Cardiovascular } \\
\text { disease. } \\
\text { Several } \\
\text { previous } \\
\text { suicidal } \\
\text { attempts. }\end{array}$ & $\begin{array}{l}\text { Verapamil } \\
24,000 \mathrm{mg} \text { (as } \\
\text { extended } \\
\text { release tablets } \\
240 \mathrm{mg} \text { ) } \\
\text { Escitalopram } \\
280 \mathrm{mg}\end{array}$ & 3 days & $\begin{array}{l}12 \mathrm{~h} \text { after intake: } \\
\text { Somnolent. } \\
\text { BP } 80 / 35 \mathrm{mmHg}, \mathrm{HR} 35 \\
\text { increasing to } 50 \text {. } \\
\text { Anuria. } \\
\text { Muscle twitches and } \\
\text { cramps in the } \\
\text { extremities. }\end{array}$ & $\begin{array}{l}\text { ABG: pH 7.33, BE -10.8, } \\
\text { lactate } 1,6-3,2 \mathrm{mmol} / \mathrm{I} \\
\text { P-glucose } 9.1 \mathrm{mmol} / \mathrm{l} \\
\text { P-calcium (ion)1.17 } \\
\text { mmol// } \\
\text { Increasing creatinine } \\
\text { ECG: Initially AV nodal } \\
\text { rhythm, atrial } \\
\text { fibrillation with LBBB }\end{array}$ & $\begin{array}{l}\text { Gastric aspiration (without lavage) } \\
\text { without any tablets retrieved. } \\
\text { Activated charcoal - single dose. } \\
\text { Atropine, Isoprenaline, } \\
\text { norepinephrine (up to } 0.56 \mu \mathrm{gg} / \mathrm{kg} / \\
\text { minute), epinephrine (up to } 0.4 \mathrm{\mu g} / \\
\mathrm{kg} / \text { minute). } \\
\text { Levosimendan. } \\
\text { Other: Plasmapheresis and CRRT, } \\
\text { temporary pacemaker (bradycardia), } \\
\text { non-invasive ventilation due to car- } \\
\text { bon dioxide retention }\end{array}$ \\
\hline $\begin{array}{l}\text { Male, } 49 \\
y\end{array}$ & $\begin{array}{l}\text { Anxiety } \\
\text { Periodic } \\
\text { Depression, } \\
\text { Epilepsy. }\end{array}$ & $\begin{array}{l}\text { Verapamil (as } \\
\text { extended } \\
\text { release tablets } \\
240 \mathrm{mg} \text { ) } \\
\text { Quetiapine } \\
\text { Codeine } \\
\text { Acetaminophen } \\
\text { Tramadol } \\
\text { Topiramate }\end{array}$ & $2 \mathrm{~h}$ & $\begin{array}{l}\text { Within } 12 \mathrm{~h} \text { after intake: } \\
\text { GCS } 3 . \text { Temperature } 32,5 \\
{ }^{\circ} \mathrm{C} \text {. Seizure in ambulance, } \\
\text { BP low, cold and pale. } \\
\text { Low urine production. }\end{array}$ & $\begin{array}{l}\text { ABG: } \mathrm{pH} 6.88 \text {, lactate } \\
11.3 \text { mmol/L. } \\
\text { ECG: ST-depression V2- } \\
\text { V6 turning into first } \\
\text { bradycardia, then PEA } \\
\text { and finally cardiac } \\
\text { arrest. }\end{array}$ & $\begin{array}{l}\text { Gastric aspiration (without lavage) } \\
\text { with small amounts of tablets } \\
\text { retrieved. Activated charcoal - single } \\
\text { dose. } \\
\text { Endotracheal intubation } \\
\text { Atropine, epinephrine, } \\
\text { norepinephrine, phenylephrine, } \\
\text { Other: Sodium bicarbonate, calcium, } \\
\text { dobutamine, naloxone } \\
\text { After PEA: Glucagon, amiodarone, } \\
\text { infusion with insulin-glucose (high } \\
\text { dose). }\end{array}$ \\
\hline $\begin{array}{l}\text { Female } \\
76 \text { y }\end{array}$ & $\begin{array}{l}\text { Obesity. } \\
\text { COPD. } \\
\text { Arterial } \\
\text { hypertension. } \\
\text { Anxiety } \\
\text { disorder, } \\
\text { Several } \\
\text { previous } \\
\text { suicidal } \\
\text { attempts. }\end{array}$ & $\begin{array}{l}\text { Verapamil } \\
\text { Acetaminophen } \\
\text { ozaxepam }\end{array}$ & $12 \mathrm{~h}$ & $\begin{array}{l}\text { Time unknown. } \\
\text { Admission status: } \\
\text { GCS 9. Temperature } 32,7 \\
{ }^{\circ} \mathrm{C} \text {. } \\
\text { BP } 80 / 50 \mathrm{mmHg}, \mathrm{HR} 40 \\
\text { initially increases to } 65 . \\
\text { AKI. } \\
\text { Myoglobin } 1167 \mathrm{\mu g} / \mathrm{L} \text {. }\end{array}$ & $\begin{array}{l}\text { ABG: pH 7.2, BE 3, } \\
\text { lactate } 2.4 \mathrm{mmol} / \mathrm{L} \\
\text { P-glucose } 16,1 \mathrm{mmol} / \mathrm{L} \\
\text { ECG: Bradycardia, 3rd } \\
\text { degree AV-block, asys- } \\
\text { tole turning into car- } \\
\text { diac arrest. }\end{array}$ & $\begin{array}{l}\text { (GID not performed) } \\
\text { Atropine, isoprenaline, } \\
\text { norepinephrine (up to } 0.7 \mu \mathrm{g} / \mathrm{kilo} / \\
\text { minute), epinephrine }(0.4 \mathrm{\mu g} / \mathrm{kilo} / \\
\text { minute). } \\
\text { Other: Flumazenil, } \mathrm{N} \text {-acetylcysteine, } \\
\text { calcium, dopamine, sodium bicar- } \\
\text { bonate, naloxone. }\end{array}$ \\
\hline $\begin{array}{l}\text { Female } \\
63 y\end{array}$ & Unknown. & $\begin{array}{l}\text { Amlodipine } 425 \\
\text { mg, } \\
\text { Metoprolol } \\
4250 \mathrm{mg} \\
\text { Enalapril }\end{array}$ & 2 days & $\begin{array}{l}6 \mathrm{~h} \text { after intake: } \\
\text { Comatose. } \\
\text { MAP 50, HR } 44 \text { (SR), cold. } \\
\text { Anuria. }\end{array}$ & $\begin{array}{l}\text { ABG: } \mathrm{pH} 7.1, \mathrm{BE}-19.8 \text {, } \\
\text { lactate } 17 \mathrm{mmol} / \mathrm{L} \text {. } \\
\text { ECG: Atrioventricular } \\
\text { Junctional Rhythm } \\
\text { (25-40 bpm) }\end{array}$ & $\begin{array}{l}\text { Gastric aspiration (without lavage) } \\
\text { with unknown result. Activated } \\
\text { charcoal - single dose. } \\
\text { Endotracheal intubation, controlled } \\
\text { ventilation with high oxygen } \\
\text { demand. }\end{array}$ \\
\hline
\end{tabular}


Table 2 Fatal cases (Continued)

\begin{tabular}{|c|c|c|c|c|c|}
\hline $\begin{array}{l}\text { Gender } \\
\text { and age }\end{array}$ & Comorbidity & $\begin{array}{l}\text { Anamnestic } \\
\text { drug exposure } \\
\text { (doses noted if } \\
\text { known) }\end{array}$ & $\begin{array}{l}\text { Interval to } \\
\text { presentation } \\
\text { and death } \\
\text { post intake }\end{array}$ & $\begin{array}{l}\text { Clinical presentation at } \\
\text { hospital } \\
\text { Time from intake to } \\
\text { admission if known) and } \\
\text { symptoms (GCS, } \\
\text { temperature, } \\
\text { hemodynamic, renal, } \\
\text { other }\end{array}$ & $\begin{array}{l}\text { Paraclinical parameters } \\
\text { Arterial blood gas ( } \mathrm{pH} \text {, } \\
\text { base excess, lactate) } \\
\text { blood samples (e.g. } \\
\text { glucose, calcium,) and } \\
\text { ECGs }\end{array}$ \\
\hline
\end{tabular}

$\begin{array}{lll}\text { Female, } & \text { COPD. } & \text { Verapamil } 6000 \\ 61 \mathrm{y} & \text { Depression. } & \mathrm{mg} \\ & \text { Multiple } & \text { Ramipril } 150 \mathrm{mg} \\ & \text { previous } & \text { Ibuprofen } 20 \mathrm{~g} \\ & \text { suicide } & \text { Zolpidem 200 } \\ & \text { attempts. } & \mathrm{mg}\end{array}$

\begin{tabular}{|c|c|c|c|}
\hline $\begin{array}{l}\text { Male, } 83 \\
y\end{array}$ & $\begin{array}{l}\text { Paranoid } \\
\text { psychosis } \\
\text { Cerebral } \\
\text { infarction } \\
\text { Dementia } \\
\text { Arterial } \\
\text { hypertension. } \\
\text { Aortic valve } \\
\text { insufficiency. }\end{array}$ & $\begin{array}{l}\text { Felodipine } \\
\text { (as } 5 \text { mg tablets) } \\
\text { Acetaminophen } \\
10 \mathrm{~g} \\
\text { Baclofen } \\
\text { Quinine } 4 \mathrm{~g} \text {, } \\
\text { Acetylsalicylic } \\
\text { acid (as } 75 \mathrm{mg} \\
\text { tablets) }\end{array}$ & 8 days \\
\hline $\begin{array}{l}\text { Male, } 30 \\
y\end{array}$ & $\begin{array}{l}\text { Depression } \\
\text { Hypertension }\end{array}$ & $\begin{array}{l}\text { Amlodipine (as } \\
10 \text { mg tablets) } \\
\text { Acetylsalicylic } \\
\text { acid } \\
\text { (as } 75 \mathrm{mg} \\
\text { tablets) } \\
\text { Ramipril }\end{array}$ & $12 \mathrm{~h}$ \\
\hline
\end{tabular}

\author{
Time unknown. \\ Admission status: \\ Unconscious. Reacts to \\ pain. Mumbles. \\ Temperature $34,2^{\circ} \mathrm{C}$. \\ BP 60/ 35, HR 36, cold, \\ pale and sweaty. \\ Anuria.
}

ABG: pH 7.24, BE 8
P-creatinine: 207
mmol/L
P-calcium (ion): 0,96
ECG: 1 st degree AV
block,
Right bundle branch
block (pre-existing) (

Time unknown.

Admission status:

Awake and fully aware of the situation. Nausea and sweaty - otherwise as usual. ECG: Normal No further test patient leaves the hospital.
ABG: $\mathrm{pH} 7.26, \mathrm{BE}-6,8$, Activated charcoal - single dose. lactate $11.1 \mathrm{mmol} / \mathrm{L} \quad$ Endotracheal intubation. ECG: Wide QRScomplexes.

Atropine isoprenaline, noradrenaline, adrenaline, dopamine, ephedrine. Other: temporary pacemaker, calcium, glucagon, Calcium (bolus and infusion), glucagon, insulin, flumazenil. Dialysis.

After temperature increases to $39^{\circ} \mathrm{C}$ : Tazobactam/piperacillin, ciprofloxacin, metronidazole.

(GID nor performed).

adrenalin, noradrenalin

Endotracheal intubation.

Other: calcium, sodium bicarbonate, $\mathrm{N}$-acetylcysteine.

Furosemide, labetalol.

Symptomatic treatment (morphine, diazepam)

P-salicylate $0.4 \mathrm{mmol} / \mathrm{L} \quad$ Activated charcoal - single dose.
Patient leaves the hospital before any other treatment is started. The patient dies $12 \mathrm{~h}$ later of carbon monoxide poisoning.

Abbreviations: ABG Arterial Blood Gas, COPD Chronic Obstructive Pulmonary Disease, CRRT Continous Renal Replacement Therapy, ECG ElectroCardioGram, GCS Glasgow Coma Score, BE Base Excess, LBBB Left Bundle Branch Blockade, GID Gastrointestinal Decontamination

\section{Abbreviations}

(CCB): Calcium channel blocker; (DDDs): Defined Daily Doses; (DPIC): Danish Poisons Information Center; (ICD-10): International Classification of Diseases 10th Edition

\section{Acknowledgements}

None.

\section{Funding}

The authors received no funding in relation to data analysis or manuscript preparation.

\section{Availability of data and materials}

The dataset supporting the conclusions of this article are included within the article and its additional files.

\section{Authors' contributions}

MC and JTA designed the study. MC, SG and JTA performed the data analyses. JTA, SG and MC drafted the manuscript. All authors (MC, KMP, SB, SA-G, EJS, KD, TSP, JTA) contributed to editing of and approved the final manuscript.

\section{Ethics approval and consent to participate}

The study was approved by the Danish Data Protection Agency (2012-580004). In Denmark, the Act on Processing of Personal Data does not require obtained consent or ethical approval for anonymized retrospective registry studies. The Danish Patient Safety Authority approved (journal number 33013-1382/1) the retrieval of data from the DPIC database and from the local clinical departments, who forwarded then forwarded the clinical data from medical charts on non-anonymous poisoned patients.

\section{Consent for publication}

Not applicable. In Denmark, the Act on Processing of Personal Data does not require obtained consent or ethical approval for anonymized retrospective registry studies.

\section{Competing interests}

The authors declare that they have no competing interests.

\section{Publisher's Note}

Springer Nature remains neutral with regard to jurisdictional claims in published maps and institutional affiliations. 
Received: 14 September 2018 Accepted: 13 November 2018

Published online: 27 November 2018

\section{References}

1. Olson KR, Erdman AR, Woolf AD, Scharman EJ, Christianson G, Caravati EM, M.fl. Calcium Channel blocker ingestion: an evidence-based consensus guideline for out-of-hospital management. Clin Toxicol 2005;43(7):797-822.

2. Hoffman RS, Howland MA, Lewin NA, Nelson L, Goldfrank LR, Flomenbaum $\mathrm{N}$, redaktører. Goldfrank's toxicologic emergencies. Tenth edition. New York: McGraw-hill Education; 2015. 1882 s.

3. Abernethy DR, Schwartz JB. Calcium-antagonist drugs. N Engl J Med. 1999; 341(19):1447-57.

4. Levine M, Boyer EW, Pozner CN, Geib A-J, Thomsen T, Mick N, Mff. Assessment of hyperglycemia after calcium channel blocker overdoses involving diltiazem or verapami**: Crit Care Med 2007:35(9):2071-2075.

5. Lynge E, Sandegaard $J$, Rebolj M. The Danish National Patient Register. Scand J Public Health. 2011;39(7 Suppl):30-3.

6. Helweg-Larsen K. The Danish register of causes of death. Scand J Public Health. 2011;39(7 Suppl):26-9.

7. Pedersen CB. The Danish civil registration system. Scand J Public Health 2011;39(7 Suppl):22-5.

8. Schmidt M, Hallas J, Laursen M, Friis S. Data resource profile: Danish online drug use statistics (MEDSTAT). Int J Epidemiol. 2016;45(5):1401-1402g

9. Hetterich N, Lauterbach E, Stürer A, Weilemann LS, Lauterbach M. Toxicity of Antihypertensives in unintentional poisoning of young children. J Emerg Med. 2014:47(2):155-62.

10. Benson BE, Spyker DA, Troutman WG, Watson WA, Bakhireva LN. Amlodipine toxicity in children less than 6 years of age: a dose-response analysis using national poison data system data. J Emerg Med. 2010;39(2):186-93.

11. Ranniger C, Roche C. Are one or two dangerous? Calcium Channel Blocker Exposure in Toddlers. J Emerg Med. 2007;33(2):145-54.

12. Truitt CA, Brooks DE, Dommer P, LoVecchio F. Outcomes of unintentional beta-blocker or Calcium Channel blocker overdoses: a retrospective review of poison center data. J Med Toxicol. 2012;8(2):135-9.

13. Marraffa JM, Cohen V, Howland MA. Antidotes for toxicological emergencies: a practical review. Am J Health Syst Pharm. 2012;69(3):199-212.

14. St-Onge M, Anseeuw K, Cantrell FL, Gilchrist IC, Hantson P, Bailey B. M.fl. Experts consensus recommendations for the Management of Calcium Channel Blocker Poisoning in adults. Crit Care Med marts. 2017:45(3):e306-15.

15. St-Onge M, Archambault P, Lesage N, Guimont C, Poitras J, Blais R. Adherence to calcium channel blocker poisoning treatment recommendations in two Canadian cities. Clin Toxicol Phila Pa. 2012;50(5):424-30.

16. Darracq MA, Thornton SL, Do HM, Bok D, Clark RF, Cantrell FL. Utilization of hyperinsulinemia euglycemia and intravenous fat emulsion following poison center recommendations. J Med Toxicol Off J Am Coll Med Toxicol. 2013:9(3):226-30

17. Belson MG, Gorman SE, Sullivan K, Geller RJ. Calcium channel blocker ingestions in children. Am J Emerg Med. 2000;18(5):581-6.

18. Deters M, Bergmann I, Enden G, Kutz S, Liebetrau G, Plenert B, M.fl. Calcium channel antagonist exposures reported to the poisons information center Erfurt. Eur J Intern Med 2011;22(6):616-620.

19. Mowry JB, Spyker DA, Cantilena LR, McMillan N, Ford M. 2013 annual report of the American Association of Poison Control Centers' National Poison Data System (NPDS): 31st annual report. Clin Toxicol. 2014;52(10):1032-283.

20. Zyoud SH, Al-Jabi SW, Sweileh WM, Waring WS. Scientific research related to calcium channel blockers poisoning: bibliometric analysis in Scopus, 19682012. Hum Exp Toxicol. 2015;34(11):1162-70.

Ready to submit your research? Choose BMC and benefit from:

- fast, convenient online submission

- thorough peer review by experienced researchers in your field

- rapid publication on acceptance

- support for research data, including large and complex data types

- gold Open Access which fosters wider collaboration and increased citations

- maximum visibility for your research: over $100 \mathrm{M}$ website views per year

At $\mathrm{BMC}$, research is always in progress.

Learn more biomedcentral.com/submissions 